Васейко, Юлія, і Масицька, Тетяна. «Особливості функціонування іменного складеного присудка в законодавчому різновиді офіційно-ділового стилю (на матеріалі Конституції Республіки Польща)». Лінгвостилістичні студії, вип. 14, 2021, с. 15-25.

Vaseiko, Yuliia, and Masytska, Tetiana. "Peculiarities of Compound Nominal Predicate Functioning in Legal Documents Substyle of Business Language (a Case Study of the Constitution of the Republic of Poland)". Linguostylistic Studies, iss. 14, 2021, pp. 15-25.

УдК 811.162.1'276.6'367.332.7:342(438)"1921"

https://doi.org/10.29038/2413-0923-2021-14-15-25

\title{
ОСОБЛИВОСТІ ФУНКЦІОНУВАННЯ ІМЕННОГО СКЛАДЕНОГО ПРИСУДКА У ЗАКОНОДАВЧОМУ РІЗНОВИДІ ОФІЦІЙНО-ДІЛОВОГО СТИЛЮ (НА МАТЕРІАЛІ КОНСТИТУЦІЇ РЕСПУБЛІКИ ПОЛЬЩА)
}

\author{
Юлія Васейко \\ Волинський національний університет імені Лесі Українки, \\ Луцьк, Україна \\ Тетяна Масицька \\ Волинський національний університет імені Лесі Українки, \\ Луцьк, Україна
}

У статті вивчено особливості функціонування в законодавчому різновиді офіційно-ділового стилю іменного складеного присудка, з'ясовано, що, попри структурну однотипність, згадана синтаксична категорія $\epsilon$ продуктивним способом виразу предикативної ознаки у тексті Конституції Республіки Польща, досліджено, що найвищою частотністю вживання вирізняються присудки зі зв'язкою bус́ та дієприкметниковим призв'язковим компонентом, дещо нижчою 3 іменниковим та прикметниковим, котрі сприяють більш стислому викладенню змісту, генеруванню модальної семантики, точним номінаціям.

Ключові слова: законодавчий підстиль, синтаксис, зв'язка, призв'язковий іменний компонент.

\section{PECULIARITIES OF COMPOUND NOMINAL PREDICATE FUNCTIONING IN LEGAL DOCUMENTS SUBSTYLE OF BUSINESS LANGUAGE (A CASE STUDY OF THE CONSTITUTION OF THE REPUBLIC OF POLAND)}

\author{
Yuliia Vaseiko \\ Lesya Ukrainka Volyn National University, Lutsk, Ukraine \\ Tetiana Masytska \\ Lesya Ukrainka Volyn National University, Lutsk, Ukraine
}

The article elucidates the study findings regarding the specific functioning features of a Compound Nominal Predicate in legal languge style. A case study material is the Constitution of the Republic of Poland. In the process of lingual-stylistic analysis of Compound Nominal Predicates identified in the document, it was found out that a Compound Predicate is quite

(C) Васейко Ю., Масицька Т., Волинський національний університет імені Лесі Українки, 2021.

Це стаття відкритого доступу на умовах CC BY-NC 4.0 
productive in this style. In the focus of analysis are the lexico-grammatical means of expressing predicatives. Being a frequent occurrence in business language, this category has both general features of functioning, characteristic for all predicates, and specific ones, characteristic only of a Compound Nominal Predicate. The linking verb types in the abovementioned syntactic category in the sentences from the text of the Constitution of the Republic of Poland are not diverse. $90 \%$ of constructions have a predicate with a linking verb być in different tenses and forms (most often in the Present tense of Indicative Mood of the third person singular or plural). From a morphological point of view, the predicative element is most productively expressed by nouns in the Common Case and an adjective or Participle form in the Common Case.

To express a predicative feature, the text of the Basic Law of Poland actively uses a polynomial compound predicate, which, due to its specific organization, is characterized by multifunctional capacity and causes some difficulty in expressing lexical and grammatical meanings, productively conveys the semantics of the objective modality, which determines the reality or unreality of the sentence content. Despite a high frequency of operation, this syntactic category is not particularly diverse. Thus, the first component of the linking part of the predicate, the modal auxiliary verb, is almost in $100 \%$ cases represented by the word móc in the form of the Present tense of the third person singular, its second component is expressed by the infinitive być, but the predicate nominative part is mostly expressed by Participle in the form of a noun, much less often - by a noun in the instrumental case. The business style is characterized by the use of stable formulas that serve as the nominative part of the Compound Nominal Predicate and are a combination of two or more words between which there are semantic and grammatical connections. Lexically structural components are so interconnected that they express a single concept.

The case study of the text of the Constitution of the Republic of Poland has revealed that, although the organization of a predicate is not characterized by a diversity of structure, the method of expressing a predicative feature in syntactic constructions with the help of a Compound Nominal Predicate is rather productive, demonstrating the highest frequency of using Participle, Nominative and Adjectives in the predicative part.

Key words: language of legal documents, syntax, linking verb, special nominative component.

Вступ. Законодавчі документи будь-якої держави $є$ потужним джерелом інформації про реалії політичного, економічного, соціального життя країни, національну свідомість, культуру, систему константних цінностей їі громадян. Невипадково згадані тексти привертають дедалі більшу увагу науковців, котрі вивчають їхнє функціональне навантаження, зміст, лінгвальні особливості.

Ділова мова вирізняється стилістичною своєрідністю, що проявляється, зокрема, у складній синтаксичній організації, якій притаманні консерватизм і архаїчність. Свою специфіку має спосіб вираження предикативної ознаки. Так, смислове наповнення й призначення законодавчих текстів зумовлюють високу частотність вживання іменного складеного присудка.

Питання про іменний складений присудок $є$ одним з недостатньо опрацьованих як у польському мовознавстві, так і слов'янському. Ще два століття тому М.Ломоносов, М.Греч, О.Потебня, О.Шахматов та інші науковці розробили граматичну синтаксичну теорію цієї категорії, заклавши основи для майбутніх лінгвістичних розвідок. Попри те, що 
історія аналізу непростого присудка є досить тривалою, ми й сьогодні не маємо універсального вчення щодо функціонування згаданого члена речення в мові загалом, у її певному функціональному стилі зокрема.

Дослідженням іменного складеного присудка займалося багато польських лінгвістів (3. Клеменсевич, П. Бонк, В. Дорошевський, М. Яворський, В. Шобер, А. Нагурко, Р. Гжегорчикова, Й. Токарський, С. Йодловський та інші). Проте у їхніх поглядах на природу названої синтаксичної категорії, iї структуру немає одностайності. Виникає чимало труднощів, пов'язаних із розмежуванням простого присудка із залежними другорядними членами речення та іменного складеного, недостатньо вивчена стилістична маркованість останнього.

Мета дослідження - з'ясувати особливості функціонування іменного складеного присудка, його структури, частоти вживання в законодавчому різновиді офіційно-ділового стилю польської мови.

Матеріал і методи дослідження. Матеріалом для проведення лінгвостилістичного аналізу став текст основного закону Польщі, що закріплює суспільний і державний устрій країни, визначає функції органів влади, права та обов'язки польських громадян. Чинну Конституцію Республіки Польща ухвалили 2 квітня 1997 року на спільному засіданні палат, а 25 травня того ж року затвердили на референдумі.

Специфіка досліджуваного об'єкта та мета нашої розвідки зумовили використання таких лінгвістичних методів і методик, як: структурнотипологічного (вивчення будови іменного складеного присудка), описового (аналіз смислового наповнення призв'язкового компонента), функціонального (з'ясування ролі непростого присудка у вираженні предикативної ознаки), статистичного (визначення частотності вживання різновидів згаданого головного члена речення у законодавчих текстах).

Результати дослідження та дискусія. Одним з актуальних завдань сучасної лінгвістики $€$ вивчення призначення, структури та мовних особливостей текстів офіційно-ділового стилю 3 огляду на їхнє непересічне значення як у внутрішній (законодавчій та адміністративноканцелярській сферах), так і в зовнішній (дипломатичній галузі, на міжнародній арені) діяльності держави, котре полягає у «повідомленні громадянам, установам і організаціям законів, постанов, розпоряджень, угод та іншої офіційної інформації, що виникає і вступає в дію чи виводиться з обігу на всіх рівнях державного, суспільного, громадського і виробничого життя» (Мацько, Сидоренко, і Мацько 259). Зразки цього стилю «діють не на почуття, натомість на волю адресата» (переклад із польської мови тут і далі - Ю.В.) (Kurkowska, i Skorupko 261), в них «якнайменше виявляється індивідуальність мовця» (Дудик 69), а «зв'язок між учасниками комунікативного акту $є$ формальним» (Wojtak 160). Згаданому стилеві властива стандартизованість, відсутність образності, лаконічність, компактність, послідовність, безособовість, об'єктивність подачі інформації з домінуванням письмової форми її презентації. 
Попри вузьку сферу застосування, офіційно-діловий стиль має свої різновиди, кожен з яких обслуговує той чи той сектор адміністративноправової діяльності держави. У польській лінгвістиці вирізняють канцелярський (styl wypowiedzi kancelaryjnych; urzędowo-kancelaryjny) та правовий (styl aktów prawnych; prawno-urzędowy) (Wojtak 155) гатунки. На нашу думку, більш влучною $\epsilon$ українська класифікація, за якою «в офіційно-діловому стилі визнають існування трьох підстилів: законодавчого (мова законів), дипломатичного (мова міжнародних документів), адміністративно-управлінського (ділові папери)» (Дорошенко 151). Саме на останньому зосереджують свою увагу дослідники, проте два інші теж виконують потужне функціональне навантаження, мають своєрідне вербальне вираження змістового наповнення. Так, законодавчий різновид реалізує вагому соціальну роль, оскільки з його допомогою загальнозначущі воля й інтереси набувають державного визнання, інформація про непересічні події потрапляє до членів національної громади зокрема, світової загалом.

«Законодавчий підстиль складають документи, які виконують настановчо-регулювальну функцію в державному та суспільному житті, утверджують обов'язкові правові норми: декрети, закони, кодекси, конституції, укази, постанови, рішення» (Мацько, Сидоренко, і Мацько 258).

Функціональне призначення законодавчих текстів зумовлює особливості їхнього змістового оформлення, якому властива логічність формулювань, нормативність, відсутність у вербальному просторі експресивно-емоційних елементів. «Мова цих документів, хоч і насичена юридичною термінологією, ускладненими синтаксичними конструкціями з відокремленням, підрядністю, повинна бути доступною і зрозумілою кожному громадянинові держави, бо всі мають однакове конституційне право на таку законодавчу інформацію» (Мацько, Сидоренко, і Мацько 258), вона тяжіє до чіткості, адже «щоб дотримуватися рішень і положень, необхідно передусім точно їх зрозуміти» (Kurkowska, i Skorupko 270). Законодавчі тексти характеризує висока продуктивність вживання суспільно-політичної лексики й фразеології, термінів та понять з галузі цивільного, кримінального, адміністративного права, номенклатур, абревіатур, що дозволяє реципієнтам однозначно сприймати зміст таких документів, не створює передумови для суб'єктивних інтерпретацій.

Яскравим прикладом законодавчого різновиду офіційно-ділового стилю $€$ текст конституції. Основний закон країни у матеріальному аспекті «писаний акт, сукупність таких актів або конституційних звичаїв, які закріплюють права та свободи людини й громадянина, основи суспільного ладу, форму правління і територіального устрою, організацію влади й управління на місцях, державну символіку та столицю. Конституція у формальному значенні - це закон або кілька законів, які мають найвищу юридичну силу щодо решти законів країни» (Конституційне право 24). 
Для свого аналізу ми обрали текст Конституції Республіки Польща, де чітко сформульовані базові засади функціонування держави, що виключає будь-яку невизначеність чи неоднозначність у їхньому трактуванні. Лінгвальне наповнення документа відповідає чинним нормам сучасної польської мови, вирізняється ясною логікою побудови речень, розділів, частин, статей. Багатство лексичних одиниць, синтаксичних конструкцій робить згаданий документ цікавим джерелом наукових досліджень.

Мовному оформленню Конституції Республіки Польща властивий високий рівень стандартизації, свідченням чого $є$ домінування книжної лексики (niepodległość, nienaruszalność, tożsamość, ustrój, wolność), усталених словосполучень (działać na podstawie, stanowi inaczej, z mocy prawa, w drodze ustawy), віддієслівних іменників (upowszechnianie, trwanie, zachowanie, wykonywanie, wywłaszczenie), дієслів третьої особи однини або множини теперішнього часу (zapewnia, stanowi, otacza, chroni, zachowuja, określaja), інфінітивів (tworzyć, ograniczać, zmuszać, naruszać), особливого синтаксису, де предикативну ознаку продуктивно виражає іменний складений присудок (Ochrona środowiska jest obowiqzkiem władz publicznych. Każdy jest obowiązany szanować wolności i prawa innych (Konstytucja) (далі цитати із Конституції Республіки Польща будемо подавати без зазначення джерела цитування)). Саме останній і став предметом нашого наукового аналізу.

У польському мовознавстві бракує єдиного терміну для означення іменного складеного присудка. Так, 3. Клеменсевич зводить поняття складного присудка (orzeczenia złożonego) як підтип вербального (orzeczenia słownego) до конструкції особової форми допоміжного дієслова зв'язки (łącznika) та іменної частини (orzecznika): jest chory (Klemensiewicz 23-24). Подібну позицію займає С. Йодловський, використовуючи у своїх розвідках термін «вербально-іменний присудок (orzeczenie słownoimienne)» (Jodłowski 71). П. Бонк та М. Яворський вживають термін «іменний присудок (orzeczenie imienne)» (Bąk 412; Jaworski 155). У нашій роботі ми послуговуємось традиційним розумінням названої синтаксичної категорії: «Іменний присудок означає рису того, на що вказує підмет (особи чи предмета) (Janek jest pracowity. Mój brat jest studentem. Dzień był pochmurny), складається з двох слів: дієслова в особовій формі та іншої частини мови. Перший компонент іменного присудка є дієсловом, котре не має самостійного значення і тому саме не може говорити про підмет. Другим ж буває найчастіше прикметник, дієприкметник, іменник, займенник, числівник і прислівник (Byłem zmęczony podróżą. On jest oficerem. Bądź zawsze sobq. Jurek był pierwszy na mecie. Pływać jest przyjemnie)» (Jaworski 155). Оскільки ці частини мови (окрім прислівника) $\epsilon$ «іменами, адже вони відмінюються за відмінками, тому такий тип присудка називають іменним» (Bąk 412).

Вивчаючи особливості вираження присудка в Конституції Республіки Польща, ми виявили, що найвища частотність вживання притаманна 
простому дієслівному: Minimalnq wysokość wynagrodzenia za pracę lub sposób ustalania tej wysokości określa ustawa. Prezydent Rzeczypospolitej wykonuje swoje zadania $w$ zakresie i na zasadach określonych $w$ Konstytucji i ustawach. Kadencja Prezydenta Rzeczypospolitej rozpoczyna się $w$ dniu objęcia przez niego urzędu. Ważność wyboru Prezydenta Rzeczypospolitej stwierdza Sąd Najwyższy. Rada Ministrów kieruje administracja rzq̨dowq̨. Zapewnia się wolność zrzeszania się $w$ zwiqzkach zawodowych, organizacjach społeczno-zawodowych rolników oraz $w$ organizacjach pracodawców. Władze publiczne popieraja rozwój kultury fizycznej, zwłaszcza wśród dzieci i młodzieży; нижча властива дієслівному складному: Sejm może wyrazić ministrowi wotum nieufności. Sejm, na wniosek Prezesa Rady Ministrów, może rozwiqzać organ stanowiący samorzqdu terytorialnego, jeżeli organ ten rażąco narusza Konstytucję lub ustawy. Organ upoważniony do wydania rozporządzenia nie może przekazać swoich kompetencji, o których mowa w ust. 1, innemu organowi. Obywatel polski nie może utracić obywatelstwa polskiego, chyba że sam się go zrzeknie.

Найпродуктивнішими, як свідчать приклади, подані вище, є форми теперішнього часу, натомість у минулому та майбутньому дієслова функціонують спорадично: Prezydent Rzeczypospolitej odwołuje ministra, któremu Sejm wyraził wotum nieufności większościa głosów ustawowej liczby posłów. Obejmując z woli Narodu urząd Prezydenta Rzeczypospolitej Polskiej, uroczyście przysięgam, że dochowam wierności postanowieniom Konstytucji, będę strzegt niezłomnie godności Narodu, niepodległości i bezpieczeństwa Państwa, a dobro Ojczyzny oraz pomyślność obywateli będq dla mnie zawsze najwyższym nakazem.

Лінгвостилістичний аналіз синтаксичних одиниць 3 іменним складеним присудком, які представлені у тексті Конституції Республіки Польща, засвідчує, що спосіб вираження предикативної ознаки за допомогою непростого присудка, призв'язковий компонент якого $\epsilon$ іменем (іменником, прикметником, дієприкметником), виявляє достатньо високу продуктивність. Будучи системним явищем в офіційно-діловому стилі, згадана категорія має як загальні особливості функціонування, характерні загалом для присудків, так і специфічні, властиві лише іменному складеному.

Зв'язковий компонент іменного складеного присудка в тексті Конституції Республіки Польща не характеризує особлива різноманітність. Найчастіше фіксуємо присудок зі зв'язкою być: Obowiazkiem obywatela polskiego jest obrona Ojczyzny. Ograniczenie wolności działalności gospodarczej jest dopuszczalne tylko $w$ drodze ustawy i tylko ze względu na ważny interes publiczny. Prezes Narodowego Banku Polskiego jest powoływany przez Sejm na wniosek Prezydenta Rzeczypospolitej, na 6 lat. Zakazane sa zrzeszenia, których cel lub działalność sq sprzeczne z Konstytucjq lub ustawq. Значно рідше натрапляємо на іменні синтаксичні конструкції зі зв'язкою zostać: $N a$ Prezydenta Rzeczypospolitej wybrany zostaje kandydat, który otrzymał więcej niż połowę ważnie oddanych głosów. Wraz ze skróceniem kadencji Sejmu skrócona zostaje również kadencja Senatu. Zmiana Konstytucji zostaje przyjęta, jeżeli za ta zmianq opowiedziała się większość głosujących. У Конституції 
Республіки Польща функціонують також присудки зі зв'язкою uważać się, котра входить до складу конструкції uważać się za kogoś / coś: Każdego uważa się za niewinnego, dopóki jego wina nie zostanie stwierdzona prawomocnym wyrokiem sqdu. Uchwałe Senatu odrzucajacq ustawę albo poprawkę zaproponowanq w uchwale Senatu, uważa się za przyjętą, jeżeli Sejm nie odrzuci jej bezwzględnq większościq głosów w obecności co najmniej połowy ustawowej liczby posłów.

Аналіз засвідчує, що автори закону дуже продуктивно послуговуються синтаксичною конструкцією з граматикалізованим дієсловом być у ролі зв'язкового компонента у формі теперішнього часу третьої особи однини чи множини. Вживання у текстах офіційно-ділового стилю слова jest $\epsilon$ явищем закономірним, адже йому властива книжна маркованість, висока частотність функціонування у формулюваннях і визначеннях, котрі мають бути логічні, чіткі, позбавлені двозначності. Оскільки jest $€$ найбільш формальною зв'язкою, яка практично втратила своє лексичне значення, тому її використання дозволяє уникати полісемічності у розумінні тих чи інших тез статей, розділів.

Крім вживання у теперішньому часі дієслів-зв'язок być, zostać, спорадично фіксуємо форми минулого й майбутнього: Marszałek Sejmu może odmówić poddania pod głosowanie poprawki, która uprzednio nie była przedłożona komisji. Orzeczenia Trybunału Konstytucyjnego $w$ sprawach wymienionych $w$ art. 188 podlegaja niezwłocznemu ogłoszeniu $w$ organie urzędowym, $w$ którym akt normatywny był ogłoszony. Jeżeli akt nie był ogłoszony, orzeczenie ogłasza się $w$ Dzienniku Urzędowym Rzeczypospolitej Polskiej „Monitor Polski”. Wybory do organów samorzqdu terytorialnego sq możliwe tylko tam, gdzie nie został wprowadzony stan nadzwyczajny. Obejmując $z$ woli Narodu urząd Prezydenta Rzeczypospolitej Polskiej, uroczyście przysięgam, że dochowam wierności postanowieniom Konstytucji, będę strzegł niezłomnie godności Narodu, niepodległości i bezpieczeństwa Państwa, a dobro Ojczyzny oraz pomyślność obywateli będą dla mnie zawsze najwyższym nakazem.

Призв'язковий компонент - іменна частина - при дієслівній зв'язці jest найчастіше виражений дієприкметником: Ograniczenie wolności działalności gospodarczej jest dopuszczalne tylko $w$ drodze ustawy i tylko ze względu na ważny interes publiczny. Cenzura prewencyjna środków społecznego przekazu oraz koncesjonowanie prasy sq zakazane. Zadania publiczne służące zaspokajaniu potrzeb wspólnoty samorzqdowej sq wykonywane przez jednostkę samorzadu terytorialnego jako zadania własne. Źródła dochodów jednostek samorzadu terytorialnego sq określone $w$ ustawie; рідше іменником: Obowiązkiem obywatela polskiego jest wierność Rzeczypospolitej Polskiej oraz troska o dobro wspólne. Rzeczpospolita Polska jest dobrem wspólnym wszystkich obywateli. Warunkiem wejścia w życie ustaw, rozporządzeń oraz aktów prawa miejscowego jest ich ogłoszenie. Posłowie sa przedstawicielami Narodu; та прикметником: Kościoły i inne zwiq̨zki wyznaniowe sa równouprawnione. Wybory do organów stanowiących sq powszechne, równe, bezpośrednie. 
Finansowanie partii politycznych jest jawne. Wszyscy sa wobec prawa równi. Postępowanie sq̨dowe jest co najmniej dwuinstancyjne.

Семантичний аналіз призв'язкового компонента іменного складеного присудка свідчить, що найвищу продуктивність має суспільнополітична та офіційно-ділова лексика, яку характеризує більша чи менша книжна маркованість: obowiq̨zek, dobro, równouprawniony, dopuszczalny, obowiq̨zany, ograniczony. Такі номени позбавлені оцінної семантики, адже їхнє функціональне призначення зводиться до номінації чи нейтральної характеристики певних реалій державних та соціальних процесів. Вони генерують атмосферу урочистості, підкреслюють непересічність подій, про які йдеться у документах, водночас роблять виклад лаконічним, виваженим (Васейко, і Цьолик 12).

Граматичний аналіз призв'язкового компонента складеного присудка показує, що найуживанішою формою іменника $\epsilon$ орудний відмінок: Ochrona środowiska jest obowiązkiem władz publicznych. Obowiązkiem obywatela polskiego jest wierność Rzeczypospolitej Polskiej oraz troska o dobro wspólne. Натомість прикметники та дієприкметники мають форму називного: Zakazana jest ekstradycja osoby podejrzanej o popełnienie bez użycia przemocy przestępstwa z przyczyn politycznych. Władze publiczne sa obowiazzane do zapewnienia szczególnej opieki zdrowotnej dzieciom, kobietom ciężarnym, osobom niepełnosprawnym i osobom w podeszłym wieku. Nauka do 18 roku życia jest obowiązkowa. Prezydent Rzeczypospolitej jest wybierany przez Naród w wyborach powszechnych, równych, bezpośrednich i w głosowaniu tajnym. Спорадично нотуємо знахідний: Każdego uważa się za niewinnego, dopóki jego wina nie zostanie stwierdzona prawomocnym wyrokiem sq̨du. Zatrzymanego należy zwolnić, jeżeli $w$ ciagu 24 godzin od przekazania do dyspozycji sądu nie zostanie mu doręczone postanowienie. Uchwałę Senatu odrzucającq ustawę albo poprawkę zaproponowang w uchwale Senatu, uważa się za przyjętą.

Природно, що в тексті Конституції Республіки Польща не зафіксовано конструкції, у яких іменний складений присудок складається 3 дієслова-зв'язки jest та іменної частини, вираженої займенником, вигуком. Такі синтаксичні конструкції не $є$ властиві законодавчим текстам, оскільки згадані частини мови вживаються здебільшого у розмовному стилі, для якого властива емоційність, образність, описовість, неточність номінацій і под. Лексика офіційних документів нейтральніша, функціонує y прямому значенні, іменники i прикметники не замінюються займенниками, дії і процеси передаються опредмечено, наприклад, через віддієслівні іменники (korzystanie, ograniczenie, kształcenie, zatrudnienie).

Варто звернути особливу увагу на стійкі словосполучення, характерні для офіційно-ділового стилю загалом, його законодавчого різновиду зокрема. У складі синтаксичної конструкції вони часто виконують функцію іменної частини непростого присудка і являють собою поєднання двох і більше лексем, між якими існують семантичні та граматичні зв'язки, котрі виражають якесь одне поняття. Такі сталі 
формули, як Godło Rzeczypospolitej Polskiej, Hymn Rzeczypospolitej Polskiej, naczelny organ kontroli państwowej, język urzędowy та інші мають семантичне ядро (godło, hymn, organ, język), проте його зміст повністю розкривається лише за допомогою означувальних слів (Rzeczypospolitej Polskiej, naczelny, urzędowy).

При функціональному аналізі до складу іменного складеного присудка відносять лише змістові центри стійких словосполучень. Ми вважаємо, що у цьому випадку варто застосувати семантичнофункціональний підхід і розглядати всю сталу формулу, а не лише смислове ядро як призв'язковий компонент головного члена речення.

У тексті Конституції Республіка Польща $\epsilon$ чимало стійких словосполучень, характерних для законодавчого підстилю. В іменному складеному присудку вони поєднуються з абстрактною зв'язкою być, а центром семантичного поля виступає іменник: Prezydent Rzeczypospolitej Polskiej jest najwyższym przedstawicielem Rzeczypospolitej Polskiej. Przewodniczacym Trybunału Stanu jest Pierwszy Prezes Sądu Najwyższego. Przedstawicielem Rady Ministrów w województwie jest wojewoda. Hymnem Rzeczypospolitej Polskiej jest Mazurek Dąbrowskiego. Prezes Rady Ministrów jest zwierzchnikiem korpusu służby cywilnej. W Rzeczypospolitej Polskiej językiem urzędowym jest język polski. Konstytucja jest najwyższym prawem Rzeczypospolitej Polskiej.

Надзвичайно високу продуктивність виявляє у тексті Конституції Республіка Польща багаточленний іменний присудок, що через свою специфічну організацію вирізняється поліфункціональним навантаженням, характеризується ускладненням вираження лексичного й граматичного значень, продуктивно передає семантику об'єктивної модальності, яка детермінує реальність чи нереальність змісту речення: Rzecznik Praw Obywatelskich nie może być bez uprzedniej zgody Sejmu pociagnięty do odpowiedzialności karnej ani pozbawiony wolności. W sprawach o szczególnym znaczeniu dla państwa może być przeprowadzone referendum ogólnokrajowe. Obowiązek pracy może być nałożony tylko przez ustawę. Przysięga może być złożona z dodaniem zdania „Tak mi dopomóż Bóg”. Структура цих синтаксичних конструкцій однотипна. Так, перший компонент ускладненої зв'язкової частини - модальне допоміжне дієслово практично 100\% представлено лексемою то́с у формі теперішнього часу третьої особи однини (часто 3 заперечною часткою nie), другий - інфінітивом być: Nikt nie może być dyskryminowany $w$ życiu politycznym, społecznym lub gospodarczym $z$ jakiejkolwiek przyczyny. Nikt nie może być poddany eksperymentom naukowym, $w$ tym medycznym, bez dobrowolnie wyrażonej zgody. Nikt nie może być obowiazany inaczej niż na podstawie ustawy do ujawniania informacji dotyczacych jego osoby. Wolność uzewnętrzniania religii może być ograniczona jedynie $w$ drodze ustawy i tylko wtedy, gdy jest to konieczne do ochrony bezpieczeństwa państwa, porządku publicznego, zdrowia, moralności lub wolności i praw innych osób. Лише спорадично фіксуємо у ролі зв'язки слово zostać: $W$ 
sytuacjach szczególnych zagrożeń, jeżeli zwykłe środki konstytucyjne sq niewystarczające, może zostać wprowadzony odpowiedni stan nadzwyczajny: stan wojenny, stan wyjq̨tkowy lub stan klęski żywiołowej. Призв'язкова ж частина здебільшого виражена дієприкметником у формі називного відмінка, значно рідше іменником в орудному: Nikt nie może być zmuszany do uczestniczenia ani do nieuczestniczenia $w$ praktykach religijnych. $W$ sprawach o szczególnym znaczeniu dla państwa może być przeprowadzone referendum ogólnokrajowe. Religia kościoła lub innego zwiq̨zku wyznaniowego o uregulowanej sytuacji prawnej może być przedmiotem nauczania w szkole, przy czym nie może być naruszona wolność sumienia i religii innych osób.

Різновиди іменного складеного (багаточленного) присудка, котрі функціонують у реченнях з тексту Конституції Республіки Польща, можна звести до таких основних типів:

1) іменниковий складений присудок: Podstawa ustroju rolnego państwa jest gospodarstwo rodzinne. Godłem Rzeczypospolitej Polskiej jest wizerunek orła białego w koronie w czerwonym polu. Jest ona nienaruszalna, a jej poszanowanie i ochrona jest obowiazkiem władz publicznych;

2) прикметниковий складений присудок: Nauka do 18 roku życia jest obowiq̨zkowa. Sędzia nie może być zatrzymany lub aresztowany, z wyjątkiem ujęcia go na gorącym uczynku przestępstwa, jeżeli jego zatrzymanie jest niezbędne do zapewnienia prawidłowego toku postępowania;

3) дієприкметниковий складений присудок: Ekstradycja obywatela polskiego jest zakazana. Prezydent Rzeczypospolitej jest wybierany przez Naród $w$ wyborach powszechnych, równych, bezpośrednich $i w$ głosowaniu tajnym. Ponowny wybór do składu Trybunału jest niedopuszczalny. Prezes Najwyższej Izby Kontroli jest powoływany przez Sejm za zgoda Senatu, na 6 lat i może być ponownie powołany tylko raz. Obywatel, któremu przekonania religijne lub wyznawane zasady moralne nie pozwalaja na odbywanie służby wojskowej, może być obowiązany do służby zastępczej na zasadach określonych w ustawie.

Висновки та перспективи дослідження. Отож, хоча організації непростого присудка не властива особлива різноманітність структури, проте спосіб вираження предикативної ознаки у синтаксичних конструкціях 3 тексту Конституції Республіки Польща за допомогою іменного складеного присудка $\epsilon$ продуктивним 3 найвищою частотністю послугування дієприкметниковим, іменниковим i прикметниковим призв'язковими компонентами, котрі сприяють більш стислому викладенню змісту, вираженню модальної семантики, точним номінаціям. у майбутньому бачимо необхідним детальніше вивчити особливості вживання згаданого головного члена речення в інших законодавчих документах, що дозволить повніше описати специфіку його функціонування у названому різновиді офіційно-ділового стилю. 


\section{Список використаних джерел}

Konstytucja Rzeczypospolitej Polski. URL: https://www.sejm.gov.pl/prawo/konst/polski/ kon1.htm.

\section{Sources}

The Constitution of the Republic of Poland. www.sejm.gov.pl/prawo/konst/ polski/kon1.htm.

\section{Список використаної літератури}

Васейко, Юлія, і Цьолик, Наталія. «Змістова організація та лексико-стилістичні особливості польської дипломатичної документації на адресу України, датованої груднем 1991 року». Лінгвостилістичні студії, вип. 12, 2020, с. 7-16.

Дорошенко, Сергій. «До питання про синтаксичні особливості законодавчого підстилю української мови». Лінгвістичні дослідження, вип. 47, 2018, с. 150-6.

Дудик, Петро. Стилістика української мови. Київ: Видавничий центр «Академія», 2005.

Конституційне право зарубіжних країн, під ред. В. Ріяка. Київ: Юрінком Інтер, 2006.

Мацько, Любов, Сидоренко, Олеся, і Мацько, Оксана. Стилістика української мови. Київ: Вища школа, 2003.

Пономарів, Олександр. Стилістика сучасної української мови. Київ: Либідь, 1993.

Bąk, Piotr. Gramatyka języka polskiego. Warszawa: Wiedza Powszechna, 2010.

Jaworski, Michał. Podręczna gramatyka języka polskiego. Warszawa: Wydawnictwo Szkolne i Pedagogiczne, 1986.

Jodłowski, Stanisław. Podstawy polskiej składni. Warszawa: Państwowe Wydawnictwo Naukowe, 1985.

Klemensiewicz, Zygmunt. Podstawowe wiadomości z gramatyki języka polskiego. Warszawa: Państwowe Wydawnictwo Naukowe,1981.

Kurkowska, Halina, i Skorupka, Stanisław. Stylistka polska. Zarys. Warszawa: Wydawnictwo Naukowe PWN, 2001.

Wojtak, Maria. "Styl urzędowy". Współczesny język polski. Lublin: Wydawnictwo Uniwersytetu Marii Curie-Skłodowskiej, 2001, s. 155-71.

\section{References}

Vaseiko, Yuliia, and Tsiolyk, Natalia. "The Content Organization and Lexical-Stylistic Peculiarities of the Polish Diplomatic Documents Addressed to Ukraine (Released in December of 1991)". Linguostylistic Studies, iss. 12, 2020, pp. 7-16.

Doroshenko, Serhii. "To the Question of the Syntactic Features of the Legislative Substyle of the Ukrainian Language". Lingvistichni doslidzhennja, iss. 47, 2018, pp. 150-6.

Dudyk, Petro. Stylistyka ukrainskoi movy. Kyiv: Vydavnychyi tsentr "Akademiia”, 2005.

Konstytutsiine pravo zarubizhnykh krain, pid red. V. Riiaka. Kyiv: Yurinkom Inter, 2006.

Matsko, Liubov, Sydorenko, Olesia, i Matsko, Oksana. Stylistyka ukrainskoi movy. Kyiv: Vyshcha shkola, 2003.

Ponomariv, Oleksandr. Stylistyka suchasnoi ukrainskoi movy. Kyiv: Lybid, 1993.

Bąk, Piotr. Gramatyka języka polskiego. Warszawa: Wiedza Powszechna, 2010.

Jaworski, Michał. Podręczna gramatyka języka polskiego. Warszawa: Wydawnictwo Szkolne i Pedagogiczne, 1986.

Jodłowski, Stanisław. Podstawy polskiej składni. Warszawa: Państwowe Wydawnictwo Naukowe, 1985.

Klemensiewicz, Zygmunt. Podstawowe wiadomości z gramatyki języka polskiego. Warszawa: Państwowe Wydawnictwo Naukowe,1981.

Kurkowska, Halina, i Skorupka, Stanisław. Stylistka polska. Zarys. Warszawa: Wydawnictwo Naukowe PWN, 2001.

Wojtak, Maria. "Styl urzędowy". Współczesny język polski. Lublin: Wydawnictwo Uniwersytetu Marii Curie-Skłodowskiej, 2001, s. 155-71. 